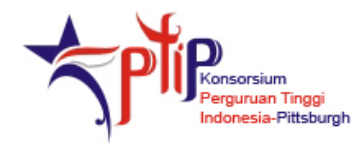

\title{
Determinants of Access and Equity in Tertiary Education: The Case of Indonesia
}

\author{
Keiichi Ogawa $^{\mathrm{a}, *}$ and Kosuke Iimura ${ }^{\mathrm{a}}$ \\ ${ }^{a}$ Graduate School of International Cooperation Studies, Kobe University, Japan
}

\begin{abstract}
How does an individual choose to pursue tertiary education in Indonesia in an era of mass tertiary education? What factors affect this decision? In this article, we analyze the determinants of access to tertiary education in Indonesia from the demand side using household survey data. We also examine the impact of regional and family background factors on inequity of access to tertiary education. In order to analyze the demand side factors for tertiary education, we use a multi-nominal logit model to examine what factors influence an individual's decision to pursue a sarjana (bachelor's) program, diploma program, or work after s/he graduates from high school. The data used is from the fourth Indonesia Family Life Survey (IFLS4) which was conducted by the RAND Corporation and others between 2007 and 2008. Key findings of the analysis are as follows: (1) the education level of the head of household and family income per household member have significant positive effects on the choice of pursuing tertiary education; (2) in urban areas, the education level of household spouse and students' test scores in high school are positively significant; (3) living in urban areas per se does not have a correlation with entry into tertiary education; (4) access to bachelor's programs for urban residents is most likely affected by the family background factors; (5) holding everything else constant, the tendency is for females to enroll in diploma programs, but not for bachelor's programs.
\end{abstract}

\begin{abstract}
Abstrak
Bagaimana seseorang memutuskan melanjutkan sekolah ke jenjang pendidikan tinggi di Indonesia ketika pendidikan tinggi sedang digalakkan secara luas? Faktor apa saja yang mempengaruhi keputusan tersebut? Dalam artikel ini, kami menganalisa faktor-faktor yang mempengaruhi akses pendidikan tinggi di Indonesia dari sisi kebutuhan individu, dengan menggunakan data survey rumah tangga. Kami juga mencermati hubungan antara akses pendidikan tinggi yang tidak merata dengan faktor wilayah dan latar belakang keluarga. Untuk menganalisa kebutuhan terhadap pendidikan tinggi, kami menggunakan model multi-nominal logit untuk mengetahui faktor yang mempengaruhi keputusan seseorang memilih kuliah program sarjana strata-1, diploma, atau bekerja setelah dia lulus dari SMA. Data ini diperoleh dari Survey Kehidupan Keluarga Indonesia ke-4 yang dilakukan oleh RAND Corporation dan para peneliti lain antara tahun 2007 dan 2008. Temuan utamanya adalah: (1) tingkat pendidikan kepala rumah tangga dan total pendapatan anggota keluarga berpengaruh positif dan signifikan terhadap putusan seseorang meneruskan pendidikan tinggi; (2) adanya hubungan positif yang signifikan antara tingkat pendidikan suami-istri dengan nilai ujian anak pada tingkat SMA/SMK, terutama pada keluarga di kota; (3) domisili di kota tidak berkorelasi dengan keputusan masuk pendidikan tinggi; (4) akses terhadap program strata-1 untuk penduduk kota lebih banyak dipengaruhi oleh faktor latar belakang keluarga; (5) dengan hal-hal lainnya tetap sama, perempuan cenderung memilih masuk program diploma, tapi tidak berlaku demikian untuk program strata-1.
\end{abstract}

Key Words: Access, Inequity, Multi-nominal Logistic Model, Regional Gap, Family Income

\section{Background of the Study}

"Massification" is a key issue for tertiary education in the twenty-first century. The number of students in tertiary education ${ }^{1}$

*Corresponding author. Address: Graduate School of International Cooperation, Kobe University, 2-1 Rokkodai-cho, Nadaku, Kobe, 657-8501, Japan. Email: ogawa35@kobe-u.ac.jp. institutions (TEIs) has been rapidly increasing in recent years while the cost of tertiary education, namely unit or per-student cost, rises continuously. The increase of tertiary level participants comes from growth of the university-age population (conventionally ages 18 through about 24). Complicating matters, both public and private higher education institutions of many countries, especially low and middle-income countries, face 
financial constraints (Johnstone and Marucci 2007). Nevertheless, many countries prioritize tertiary education in their national goals since the world that we live in today is a knowledge-based society. It is widely noted that knowledge is the engine of development in the new world economy, and is a key for economic development (Castells 1993; World Bank and UNESCO 2000; Tilak 2003). Globalization and the revolution of information and communication technology (ICT) further expand this knowledgebased society and the role of tertiary education within it.

In developing countries, low access and inequity for gender, disability, location of residence, ethnic minority, and low socioeconomic status are still phenomenal (UNESCO 2003; James 2007). Therefore, differentiated academic systems are required to address low access and inequity through education services for people with various needs (Altbach 2006). In 2009, the Second World Conference on Higher Education called on every government to increase investment in higher education and to differentiate approaches to meet the rapidly increasing demand. With this call, there is a need to analyze demand for tertiary education in detail.

\section{Tertiary Education in Indonesia}

Indonesia has experienced a rapid expansion of enrollment in tertiary education and a wider distribution of TEIs. The gross tertiary enrollment rate of Indonesia was estimated at 18 percent in 2007, and the number of students in TEIs increased from 231,000 in 1979 to 3.8 million in $2007 .{ }^{2}$ In the same year, there were 2,680 TEIs including 82 public institutions. ${ }^{3}$ In other words, most TEIs are private and have catered to rapidly increasing demand for tertiary education.

In Indonesia, TEIs are classified as an academy, polytechnic, college for specialization (sekolah tinggi), institute, or university which covers comprehensive disciplines with multiple faculties. An institute offers a single field of discipline, such as agriculture, with multiple faculties. A college for specialization is a single faculty institution. An academy and a polytechnic offer a range of courses, some of which are vocational or technical, at or below the bachelor's degree level (diploma degrees). An academy focuses on science and humanities while a polytechnic focuses on engineering and related sciences. These institutions are under the oversight of the Ministry of National Education (MONE) and the Ministry of Religious Affairs (MORA).

About a decade ago, the Government of Indonesia (GOI) established the Third Higher Education Long Term Strategy (HELTS III), which lasted from 1996-2005. The strategy identified three major issues in Indonesian tertiary education: (1) the need for more dynamic management in tertiary education to cope with the dynamic social changes; (2) the need to ensure quality and relevance for tertiary education development; and (3) the need for enhancing social mobility and equity through tertiary education development. In 1997, only one year after HELTS III was instituted, Indonesia's economy was devastated by the Asian economic crisis. The centralized approach of HELTS III could not cope with the new challenges brought on by the unprecedented crisis. As a result, the expectation to achieve geographical and social equity of enrollment was not met due to financial constraints (Directorate General of Higher Education [DGHE] 2003). Since the collapse of the Suharto Administration in 1998, GOI has promoted democratization and decentralization, and has adopted the global trends for tertiary education such as marketorientation, corporatization, and accreditation (Nishino 2006).

In 2003, the GOI established HELTS IV to strengthen the nation's competitiveness, autonomy, and organizational health. In order to enhance the nation's competitiveness, it recognizes the need for structural adjustment of the higher education system. The vision of HELTS IV was to provide all citizens with "seamless learning opportunities" in order to "grow intellectually and emotionally, be well equipped for work, and contribute effectively to society, as well as achieve personal fulfillment" (DGHE 2003, 2). Moreover, HELTS IV highlights the need to produce highly skilled labor. To do this, it must meet the demand for access to tertiary education, which has so far exceeded the capability of the system. At the same time, it is pointed out that less privileged individuals are underrepresented in tertiary education, and HELTS IV has a strong commitment to addressing the issues of income and regional inequity of access (World Bank 2005).

According to the International Comparative Higher Education Finance and Accessibility Project (ICHEFAP) (2006), enrollment in rural areas of Indonesia is less than half of that in urban areas. Moreover, Triaswati and Roeslan (2003) find that only 3.3 percent of the lowest income quintile took part in TEIs in 2001, compared to 30.9 percent of students of the highest income quintile. Access and inequity issues in tertiary education of Indonesia are described in detail later in this article. Hereinafter, "access" refers to access to tertiary education in Indonesia, and "inequity" or "access inequity" is the disparity in this access.

\section{Problem Statement}

Various studies have shown that the access gap in tertiary education has been a serious problem in Indonesia for a long time (Psacharopoulos et al. 1986; Ziderman and Albrecht 1995; Brodjonegoro 2004; ICHEFAP 2006; Nizam 2006). Meanwhile, GOE has attempted to meet the phenomena with the building up of TEIs year by year. Private institutions are helping to meet the 
rapid increase of demand for tertiary education. Interestingly, many private institutions are supported by the government. ${ }^{4}$ GOI also provides several types of institutions, degrees/diplomas/ certificates, entrance systems, ${ }^{5}$ and scholarships. For instance, a diploma is granted for programs conducted either in polytechnics, academies, or some universities. A diploma program is regarded as a more practical program compared to bachelor's, master's, and doctoral programs. A sarjana (bachelor's) program is the first academic degree in tertiary education and lasts for four or fourand-a-half years after senior secondary school (Brodjonegoro 2004). There is also an open university, Universitas Terbuka (UT) in Indonesia that provides both diploma and sarjana.

Remarkably, there have been few studies that consider the demand for tertiary education in Indonesia. One study is that of Devid O. Hansen and his colleagues (1989), who investigated the determinants of applications for universities in Indonesia. The sample collected is from those who took entrance exams in public universities and does not reflect those who did not apply, or those who applied to private institutions. Given this situation, there is a need for a demand side analysis of tertiary education in Indonesia. To address this need, this study investigates the following research questions: (1) What kinds of factors affect access to tertiary education in the case of Indonesia? (2) How can we predict an individual's behavior after graduation from senior secondary school in Indonesia? Moreover, (3) what differences of determinants exist by region?

\section{Objective of the Study}

The objectives of the study are twofold. First, this study aims to investigate the determinants of access to tertiary education in Indonesia from the demand side using a household survey, which was collected by the RAND Corporation, the Center for Population and Policy Studies (CPPS) of the University of Gadjah Mada, and Survey METRE. The data provides an enormous amount of information about the Indonesian population, including detailed educational information. It represents about 83 percent of the population, which makes it possible to comprehensively assess educational behavior.

The second objective is to examine the different determinants of access to tertiary education according to region by examining enrollment in diploma and bachelor's programs. In the Indonesian tertiary education the issue of access and inequity is prominent in terms of family income as well as region of residence. This study examines whether these factors are significant when controlling for selected variables. The demand for diploma programs should be theoretically different from that for bachelor's programs, which makes it possible to reflect the difference by region. Diploma programs are more practical than academic programs and offer relatively shorter courses. By using an econometric model, this study also assesses inequity of access to tertiary education, particularly by regional and family background factors.

\section{Significance of the Study}

To address the lack of research about demand for tertiary education in Indonesia, this study applies a demand side analysis of tertiary education based on previous studies that have been mostly conducted in developed countries. Although Hansen and his colleagues (1989) conducted an empirical study in Indonesia about the determinants of access to university education, they only analyze those who took entrance exams for public universities. Chen (2009) also conducted a similar study, but the main focus was the difference between general senior secondary schools (SMA) and vocational senior secondary schools (SMK). Chen focused neither on the difference between diploma and bachelor's programs, nor on the whole senior secondary population such as students from religious senior secondary schools (MA). More importantly, neither of the two studies considers the regional characteristics of Indonesia's considerably large and diverse tertiary education system.

This study, on the other hand, provides a comprehensive analysis of the choices made regarding the two previouslymentioned types of tertiary education programs, and the work by students who graduated from high schools. In addition, it includes regional factors, family background and other characteristics as potential determinants of access to both public and private institutions. While academic enthusiasm for tertiary education has always existed, it is again becoming an important topic in an era of mass higher education led mainly by private TEIs. This study reviews both relatively older and new literature, and also can play an essential role in educational development. HELTS IV indicates that social and regional access inequity of tertiary education has been a problem for a long time. In this sense, this study also provides a tool for decision making on the supply of tertiary education in Indonesia.

\section{Access and Inequity in Indonesian Tertiary Education}

\section{The Massification of Tertiary Education in Indonesia}

GOI acknowledges its strong commitment to human resource development and education in the second 25-Year Long-Term Development Plan (PJP II), which began in 1994. Indonesia has tried to achieve scientific and technological excellence, and has noticed the necessity for quality human resources (Brodjonegoro 
2004). Tertiary education in Indonesia has rapidly grown in terms of access. In 2007, there were more than 3.8 million students enrolled in 2,860 TEIs, which means that Indonesia has the largest population and TEIs among South-East Asian countries (Zhang 2008). According to Nizam (2006), the rapid expansion has not been the result of effective planning and funding mechanisms. Instead, it has been driven by high economic growth due in part to the oil price boom during the late 1970s and early 1980s. The number of students enrolled in TEIs increased from around 200,000 in 1975 to 2.5 million by 1995 . Currently, over 450,000 students completing high school take the national public exam every year and compete for 75,000 seats (Nizam, 2006). Indonesian tertiary education is undoubtedly placed in the trend of massifcation, with an estimated enrollment rate in 2007 of more than 18 percent according to UNESCO. ${ }^{6}$ Figure 1 shows the gross tertiary enrollment ratios of selected neighboring countries in Asia and the Pacific. While the ratio of Indonesia is higher than that of India, Cambodia, and Bangladesh, it is still lower than Thailand, Malaysia, the Philippines, and China.

Figure 1. GER of Tertiary Education in Asia and the Pacific, Latest Year in $2000 \mathrm{~s}$

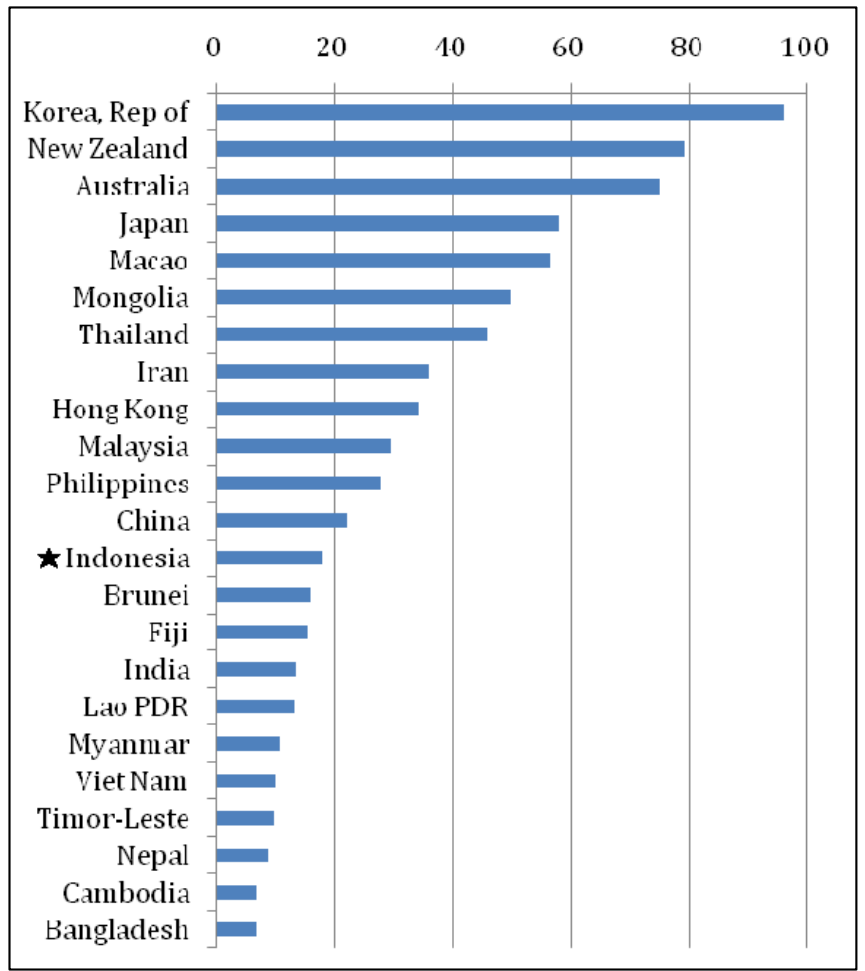

Source: Created by Authors based on UNESCO and WB data bases.

\section{Returns to Tertiary Education in Indonesia}

Although the above section has focused on the increase of the demand in terms of enrollment, the simple question arises: why do students demand tertiary education in Indonesia? One explanation used in most of the economics literature is to treat education as an investment in human capital (Schultz 1961; Becker 1964). According to human capital theory, students are economic individuals who invest in education if the expected benefits from the investment are greater than the direct and indirect costs. Figure 2 shows the age-earnings profiles by level of education based on the household survey in 2007 . $^{7}$

Figure 2. Age-Earnings Profiles by Level of Education, 2007

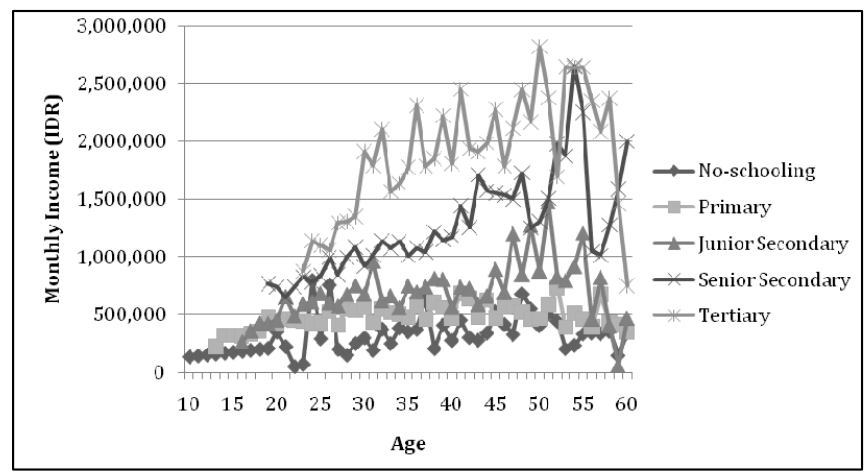

Source: Created by Authors based on IFLS4 (2007).

Figure 2 indicates the average monthly income by level of education in each age group from 10 to 60 . It is perceived that tertiary education degrees bring relatively high income in the future. Overall, the evidence shows that the higher the level of education attained, the greater the earnings in the labor market are, as human capital theory suggests.

To grasp the demand for education, this study calculates the rates of return to education for an individual. Table 1 shows the private rates of return to education in Indonesia based on 2007 household survey data.

The private rate of return to tertiary education is modest, estimated at 13.8 percent. The return to primary education is relatively small, perhaps due to almost universal enrollment in primary education. Secondary education, particularly senior secondary education, has a higher rate of return than both primary and secondary education. This implies that employees with tertiary-level qualifications in Indonesia are not as highly valued by the labor market as those in other Asian countries. Although a simple comparison is difficult, the average return to education in Asia shows a different distribution from those in Indonesia, where 
tertiary education has the highest return. In Indonesia, the demand for tertiary education is increasing, but seemingly, is not simply related to a higher expected return in the labor market.

Table 1. The Returns to Education in Indonesia, Earning Function Method (\%)

\begin{tabular}{lcc}
\hline Education Level & \multicolumn{2}{c}{ Private Rates of Return } \\
\hline & Indonesia* & Average in Asia \\
\cline { 2 - 3 } Primary & 5.1 & 18.2 \\
Junior Secondary & 14.6 & 15.8 \\
Senior Secondary & 17.5 & 20.0 \\
Tertiary & 13.8 & \\
\hline
\end{tabular}

*Following Psacharopoulos (1995), the extended earning function method is used to calculate the private rates of return to education in Indonesia. The estimated regression equation is:

Linage $=$

$11.280+0.058$ exper -0.001 exper ${ }^{2}+0.305$ pmintary $+0.744 / \eta_{\text {es }}+1.268$ she $_{\text {se }}+1.820$ tentiary + 0.010 howr s $s_{\text {marked }}+$ wh.

$\mathrm{N}=8,988, \mathrm{R}=0.333, \overline{\mathrm{K}}=0.333$

Note: OECD countries are excluded in Asian countries here. The full method is used for the average in Asia.

Source: Created by Authors based on 2007 IFLS and Psacharopoulos and Patrinos (2002).

\section{Issues in Access to Tertiary Education}

Due to limited government resources, the Indonesian tertiary education system does not have enough capacity to accommodate increasing demand. Even though private institutions compensate for the lack of government capacity, the university admission system is highly competitive (Nizam 2006). To be admitted to public universities, students must score high marks on an entrance examination, which often requires prior access to a quality high school, or the ability to pay for extra tuition. Ninety-seven percent of TEIs are private institutions. These institutions set much higher fees since they are operated by private foundations and their budgets are almost entirely tuition driven. It is obvious that students from poor families are disadvantaged. Mochtar Buhori and Abdul Malik (2006) argue that it is often the case that Indonesian students enter a private university as a result of failing to be accepted to a public university. Many students who belong to low-quality and accessible private universities are from families with low socioeconomic status. Thus, the publicly funded state institutions are more accessible to families with high and middle socioeconomic status, and inequity of access to tertiary education will become a permanent condition.

Access inequity to tertiary education is not a new problem in Indonesia. Psacharopoulos and colleagues (1986) examined which income groups benefited the most from subsidies for higher education. The results are shown in Table 2 below.
In Indonesia, the top income group, or top 30 percent, benefited from 83 percent of the subsidies, while the bottom 40 percent enjoyed just 7 percent in 1978. Compared to other educational levels, a large inequity of access to tertiary education is still observed. The evidence shows that 3.3 percent of individuals from the lowest quintile, and just 4.8 percent from the second lowest quintile were enrolled in TEIs, while 30.9 percent from the highest income quintile were enrolled in tertiary education in 2001 Triaswati and Roeslan (2003). While almost universal primary education is achieved, the disparity of access to education by income group is observed even in the junior secondary level. Moreover, the higher the level of education, the greater the access gap by income group. This is because poor families are likely to expect their children to earn in the labor market rather than receive an education (Nizam 2006).

Table 2. Share of Higher Education Subsidies by Income Group (\%)

\begin{tabular}{lcccc}
\hline & & \multicolumn{3}{c}{ Income Groups } \\
\cline { 3 - 5 } Country & Year of Data & Lower & Middle & Upper \\
\hline Colombia & 1974 & 6 & 35 & 60 \\
Malaysia & 1974 & 10 & 38 & 51 \\
Indonesia & $\mathbf{1 9 7 8}$ & 7 & $\mathbf{1 0}$ & $\mathbf{8 3}$ \\
Chile & 1983 & 15 & 24 & 61 \\
\hline
\end{tabular}

Source: Psacharopoulos et al. (1986).

Gender disparity is not a problem in Indonesian tertiary education. Table 3 shows the recent trend for gross tertiary enrollment in Indonesia. The female enrollment rate has been rapidly rising, and as of 2007 , it is equivalent to the enrollment rate for males.

The data in Table 4 indicates that gender disparity is a minor issue in both urban and rural areas. In fact, the enrollment rate for females is slightly higher than the enrollment rate for males in both urban and rural settings. More importantly, the access gap by region is a serious issue in Indonesian tertiary education. In 2007, among the tertiary age population, the proportion of participants in TEIs in rural areas is just one third of that in urban areas. About 23.6 percent of urban students attend or used to attend tertiary education, while just 8.6 percent of rural residents are or were enrolled in tertiary education. The higher the level of education, the greater is the access gap by region. 
Table 3. Gross Tertiary Enrollment Rate by Gender, 2001 to 2007

\begin{tabular}{lrrrrrrr}
\hline & 2001 & 2002 & 2003 & 2004 & 2005 & 2006 & 2007 \\
\hline GER, Total & 14.8 & 15.5 & 16.7 & 17.1 & 17.5 & 17.5 & 18.0 \\
GER, Female & 12.9 & 14.4 & 14.8 & 15.1 & 15.5 & - \\
GER, Male & 16.8 & 16.6 & 18.5 & 19.0 & 19.6 & - \\
\% of Female Students & 42.8 & 45.9 & 43.9 & 43.8 & 43.7 & - & 18.0 \\
GPI & 0.8 & 0.9 & 0.8 & 0.8 & 0.8 & - \\
\hline
\end{tabular}

Note: GPI = Gender Parity Index.

Source: Created by Authors based on UNESCO data base.

Table 4. Disparity of Access to Education by Region in 2007 IFLS, Ages 19 to 25

\begin{tabular}{|c|c|c|c|c|c|}
\hline & & & & ation & \\
\hline & & Primary & Junior Secondary & Senior Secondary & Tertiary \\
\hline & Female & 99.3 & 87.1 & 67.6 & 23.8 \\
\hline Urban & Male & 99.5 & 86.8 & 70.7 & 23.4 \\
\hline & $\mathrm{F}+\mathrm{M}$ & 99.4 & 87.0 & 68.9 & 23.6 \\
\hline & Female & 99.1 & 69.9 & 40.3 & 9.1 \\
\hline Rural & Male & 98.9 & 71.5 & 44.6 & 8.0 \\
\hline All & Male & 99.2 & 79.5 & 58.1 & 16.1 \\
\hline & $\mathrm{F}+\mathrm{M}$ & 99.2 & 79.1 & 55.9 & 16.4 \\
\hline
\end{tabular}

Note: The information of region of residence is based on household's location in 2000 to grasp the situation before entrance.

Source: Calculated by Authors based on 2007 IFLS.

\section{Demand Side Analysis on Tertiary Education}

\section{Historical Perspective and Categorizing}

One of the first studies that attempted to examine the main influences on private demand for higher education ${ }^{8}$ was conducted in 1963 by the Robbins Committee on Higher Education in the United Kingdom (Menon 1998). The Robbins Committee on Higher Education considered such factors as family background, economic and employment prospects associated with different educational levels, and the institutional variables relating to the provision of primary and secondary education as the most important factors influencing entry into higher education. Since then, a lot of economic analysis has been done, mainly in developed countries, using micro-data to examine the issues of access and equity (Piachaud 1975; Bishop 1977; Psacharopoulos and Soumelis 1979; Wills and Rosen 1979; Manski and Wise 1983; Kodde and Ritzen 1988; Burnhill, Garner and McPherson 1990; Hayden and Carpenter 1990; Nakamura 1993; Menon 1998; Albert 2000; Li and Min 2001; Flannery and O'donoghue 2009).
Research on the topic has been conducted from several viewpoints, namely chronological analysis, space analysis, and models of personal characteristics. Analyses based on personal characteristics of individuals make it possible to assess the problem of inequity of access for individuals coming from different strata and areas (Mora 1997). Chronological analyses make it possible to assess the influence of time using macro data, and space analyses assess the inequity among regions or regional effects. In order to analyze private demand for education, the data used should be categorical and individual, and a discrete choice model should be used for the estimation instead of a regular regression formula (Oshio and Senoh 2003).

According to OECD (1978), individual and institutional determinants that influence the pursuit of higher education can be divided into four groups. The individual determinants are divided into student characteristics and personal environment. Student characteristics are: sex, intellectual abilities, educational achievement, interests, aspirations. The components of personal environment are: family background, peer group, and school environment. The institutional determinants are divided into 
educational system and society outside the educational system. The educational system factors indicate conditions before the choice, such as curriculum and guidance organization, and conditions anticipated in the choice situation, such as admission and selection, and predicted structural change in education. The society factors outside the educational system are demographic factors, socio-cultural conditions, occupation, and the economy including private rates of return. In general, the family is considered to be the most important factor to have an effect on the demand for higher education. For instance, an individual from a family with higher social status is likely to enjoy a better study environment, be encouraged to perform better at school, and continue to study after secondary graduation.

\section{Empirical Knowledge about the Determinants of Access}

According to Hayden and Carpenter (1990), three conceptual approaches can be identified to capture the potential determinants of access to tertiary education: economical models, sociological models, and psychological models. From an economic point of view, decisions to pursue higher education are influenced by perceived returns on the investment in tertiary education qualifications. The demand for higher education increases when the private rate of return to education is greater than the return from other investment opportunities. There are numerous studies analyzing the demand for tertiary education with this approach (Handa and Skolnik 1975; Mingat and Eicher 1982; Manski and Wise 1983; Post 1990; Jiménez and Salas-Velasco 2000). Human capital theory hypothesizes that receiving education enables an individual to accumulate human capital and determines the increase in the individual's productivity, which increases future income. It may not matter to an individual whether higher future income is caused by increased productivity or education as a signaling of an individual's ability in the labor market (Spence 1973). Moreover, Jiménez and Salas-Velasco (2000) argue the need to consider the consumption motive, as well as employment perspective, in the education demand model.

Most economic research based on personal characteristics shows the importance of family background factors. It has been widely reported that the education level of parents and, to a lesser extent family income, has a strong influence on the demand for higher education (Psacharopoulos and Soumelis 1979; Manski and Wise 1983; Kodde and Ritzen 1988; Burnhill, Garner and McPherson 1990; Hayden and Carpenter 1990; Nakamura 1993; Menon 1998; Albert 2000). Moreover, parental level of education is related to the child's choice of the type and length of his/her higher education (Budria 2006). ${ }^{9}$ According to Becker (1981), families invest in children's education, but are constrained by economic and educational resources of the families. They invest if they have the resources to spend. More importantly, the significance of these factors applies to advanced countries like the United States of America and less advanced countries with different cultural and/or economic structures (Post 1990; Li and Min 2001). On top of this, individual characteristics such as academic ability have been reported to have a strong influence. As a psychological/individual factor, student ability is commonly investigated and is often a major determinant of the student's educational aspiration (Kodde and Ritzen 1988). Student perceptions and attitudes towards higher education and work are shown to be importance (Psacharopoulos and Soumelis 1979; Jiménez and Salas-Velasco 2000). Other demographic variables such as sex, race, and ethnic origin can also impact the decision to enter higher education.

Blau and Duncan (1967) argue from a sociological point of view, that family background is also significant. The main focus of this approach is the relationship between the social origins of students such as means of home, family structure, ethnicity, region, peer group, aspiration, and the ability with achievement and entry to higher education. The importance of the cultural and familial environment in early childhood on later education is also argued (Haveman, Wolfe and Spaukling 1991), which reinforces the relevance of family characteristics to predict the children's future. When the chronological evolution of the influence of family background is analyzed, its impact on children's educational attainment is relatively low due to the extension of compulsory education and mass higher education (Carpenter and Hayden 1993), or due to the increase of individualization and the decline of ascription within some social changes (Kuo and Hauser 1995). When variables related to socioeconomic status of the neighborhood are examined, the educational level of the region where students live influence the demand for higher education (Hopkins 1974; Stafford, Lundstedt and Lynn 1984; Mora 1997). Likewise, the proximity to TEIs is reported as a significant factor (Arai 1989). Another social variable on an individual's demand for higher education is the effect of peers on educational aspirations, and the influence of teachers and career counselors (Kandel and Lesser 1970; Williams 1972; Menon 1998).

In addition to the three categories mentioned above, some studies find that institutional variables such as status of the secondary school (Meyer 1970; Nelson 1972), streaming mechanisms and points of transition within the educational system (Yuchtman and Samuel 1975), and the secondary school curriculum are all likely to affect entry into higher education. Institutional variables generally have a significant effect on the future educational paths of secondary school students, but they 
often have less impact on the demand for higher education compared to other possible influences (Menon 1998).

Lastly, from a psychological point of view, studies do not form a discrete grouping in the way that economic and sociological approaches do. Instead, they generally have a starting point with clear aspects of an individual's personality, and these aspects interact with key elements in the decision-making environment to affect behavior (Hayden and Carpenter 1990). They also point out the limitations of economic and sociological approaches. As for the economic approach, many potentially relevant considerations are absorbed by the notion of tastes and preferences, while the sociological approach is limited in how it selects relevant influences, such as distinctive motivational attributes, the existence of course quotas, and the availability of student aid so that they are not easily embedded in the approach. It is often pointed out that research using cross-sectional data to investigate the demand for higher education can be ad hoc and provide only a partial account of the influences on student choice regarding higher education (Menon 1998). However, it is also true that numerous studies have used this approach.

\section{Indonesian Context}

In the case of Indonesia, Hansen, Saleh, Flinn, and Hotchkiss (1989) show that socioeconomic status has an important effect on access to public universities, but its effect is measured through the decision to take entrance exams. Since Hansen and colleagues focused on two types of social status, ascribed status which can not be changed by any effort, and achieved statuses which can be changed by effort, they assess a more sociological issue, or the need for a meritocratic system of access to education. The authors recognized that they examined those who took entrance exams (about 16 percent of the age cohort) and the applicants for private universities. Their study does not reflect the demand for higher education representative of the complete population.

On the other hand, Chen (2009) uses relatively more complete data and shows the factors predicting the likelihood of participation in tertiary education, focusing on the effect of vocational secondary schools (Sekolah Menengah Kejuruan [SMK]). Chen indicates that attendance at SMK has a significant negative impact on test scores, ${ }^{10}$ and if omitting test scores, it reduced the chance of entering tertiary education. She concludes that there is no stigma attached to attendance at SMK that results in a disadvantage in access to tertiary education. Chen also shows the importance of parents' educational attainment and family income to influence access to tertiary education. Family income, however, affects only boys.

\section{Methodology}

\section{Conceptual Framework}

This study covered the empirical evidence of the demand and determinants of access to tertiary education, and identified that they could be broken-down into several categories. Figure 3 summarizes the four components that indicate the determinants of access to tertiary education. The data used in this study is located in the upper-left box, or the objective determinants in student characteristics, which makes it possible to focus on family income and regional characteristics.

Figure 3. Modeling Educational Choices

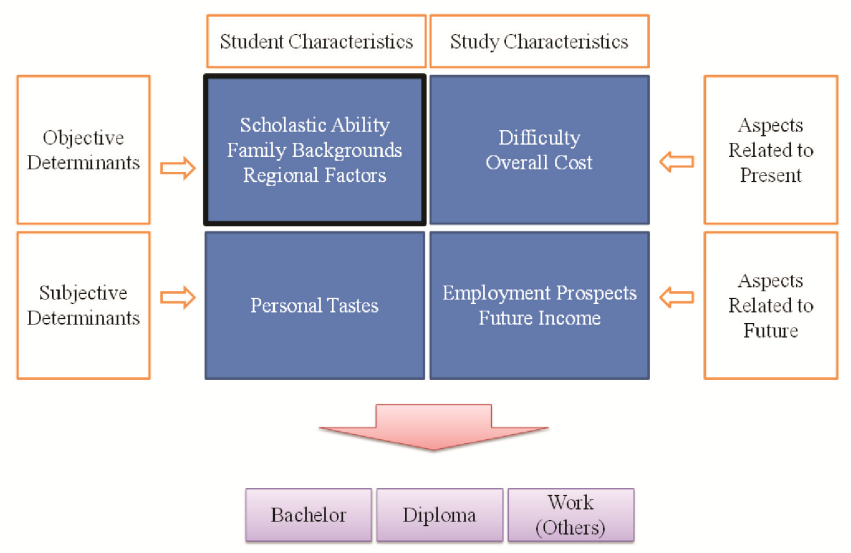

Source: Created by Authors based on Jiménez and Salas-Velasco (2000).

\section{Hypotheses}

Based on the previous studies assessing the demand for tertiary education, four categories of variables are mainly considered in the analysis, namely individual, familial, scholastic, and regional characteristics. In response to two research questions in this study, two hypotheses are discussed.

Hypothesis 1: Controlling for the selected variables, family income per household member and regional factors have significant effects on the choice to pursue tertiary education.

The Indonesian tertiary education system has serious income and regional inequity of access. Even if other selected variables are controlled for by using an econometric model, they would have effects on access to tertiary education. Two key variables, namely education level of household head and individual test 
scores while attending high schools, are considered as the best predictors of a child's choice to pursue tertiary education following the preceding studies.

Family income per household member would be significant to predict entry into tertiary education since it is the primary source to pay for tertiary education. According to previous studies (Psacharopoulos and Soumelis 1979; Jiménez and Salas-Velasco 2000), family income is likely to be a significant indicator of belonging to more privileged areas of study in tertiary education, and would yield different results between access to diploma and bachelor's programs.

Regional characteristics are considered to be a key factor on the demand for tertiary education. In particular, living in urban areas is expected to impact access to tertiary education. It is not surprising that there are many more TEIs in urban areas than in rural areas, and children living in cities can easily access TEIs. Furthermore, households living in urban areas are likely to have above average income, which affords more educational opportunities to children in those households. Statistical studies by ICHEFAP (2006) supports this, reporting that tertiary enrollment in rural areas is less than half of that in urban areas. Likewise, average schooling in the area of residence would show a peer group effect, such as environmental push and quality fellows (Psacharopoulos and Soumelis 1979). In addition, the regional income per capita would be influential on demand for tertiary education, accounting for the labor market condition. It is also expected to have a negative effect on the decision to pursue tertiary education since more students would enter the labor market if the region enjoys an economic boom and students have more opportunities to find jobs. On the other hand, young people are more likely to take any job offered rather than go on to tertiary education. Moreover, they feel the cost of obtaining tertiary qualifications is increasing while the labor market is deteriorating (Mora 1997; Hayden and Carpenter 1990). In Indonesia, however, the labor market conditions are not as stable as developed countries and there are a lot of unemployed youths due to limited job opportunities, even if they have completed tertiary education. Thus, the impact of the labor market would be more applicable in Indonesia.

Parents with better education and higher income are likely to provide a better learning environment for their children, and be willing to pay for their children's education. In Indonesia, most students enrolled in tertiary education receive financial support from their family. Previous studies show that the education level of parents has a significant positive effect in predicting the likelihood of pursuing tertiary education. The mother's educational attainment is often a better determinant rather than that of the father (Arai 1989; Albert 2000). However, education standards of Indonesia are not as high as that of developed countries where most of the previous literature is conducted. Thus, the effect of the mother's education would be limited in the case of Indonesia. Likewise, test scores administered at the end of secondary school would have a significant effect on the decision of attending tertiary education.

Other variables, such as an individual's scholastic characteristics, are also worth noting. Almost all previous studies include an analysis of gender. Often being a female often has a significant positive effect on predicting the likelihood of entering tertiary education. However, there is no gender disparity in terms of enrollment rates of tertiary education in Indonesia. Even so, this study includes the variable for the estimation. The number of siblings is also correlated with entry into tertiary education. It is expected to have a negative effect since it imposes financial constraints on the household budget. Student test scores and working status are also used as key variables. Working status while attending high school would reveal demand for diploma programs. Working high school students need a more practical degree in order to compete in the labor market.

Hypothesis 2: In rural areas, family income per household member and education level of householder are especially important on children's access to tertiary education, compared to urban areas.

It is widely discussed that urban residents are more likely to enjoy the opportunities of tertiary education and the evidence shows an enrollment gap between regions in Indonesia. In urban areas, societies are relatively developed and the determinants of access to tertiary education would be similar to those in the previous literature for developed countries. In this sense, family income and education level of household head in urban areas would be more influential on the demand for tertiary education compared to rural areas. Individual and scholastic characteristics would also be greater determinants for students living in urban areas. Post (1990) shows that the cost of and the benefit from university education have little to do with labor market considerations in Peru, except in the case of the most privileged individuals (boys from urban and higher socioeconomic status backgrounds). Although this study takes into account the effect of the labor market through regional income per capita, its influence might be less in rural areas than that in urban areas, if applying Post's findings into the Indonesian case. Moreover, it implies that the variables, other than family income and education level of household head, would be less influential in less privileged areas.

In addition to the differences between regions, there would also be differences between types of tertiary education. As 
mentioned earlier, GOI provides several programs in tertiary education to meet the various demands of its citizens. Thus, it is theoretically possible that there is some difference between the demands for bachelor's programs and diploma programs, and the difference by region would perhaps appear. In order to assess the above-mentioned hypotheses, the next section builds a model of educational choices.

\section{Our Model}

A multi-nominal logit model is used to examine which factors influence an individual's decision to pursue a bachelor's program, diploma program, or-something else after s/he graduates from high school. In the multi-nominal logit model, an individual's choice of tertiary education is a function of several independent variables: family background, individual and scholastic characteristics, and additional regional factors.

The dependent variable takes a value of zero for individuals who did not attain tertiary education, or who are not enrolled in tertiary education. A value of 1 is assigned for those who have completed or are undertaking a diploma program. A value of two is used for those who have finished, or are enrolled in a bachelor's program.

The three outcome categories of this study require two logit functions. Following the work of Hosmer and Lemeshow (2000), the logit functions denoted below assume that there are $p$ covariates and a constant term as follows:

$g_{1}(\mathbf{x})=\ln \left[\frac{p(Y=1 \mid x)}{p(Y=q)}\right]=\beta_{10}+\beta_{11} x_{1}+\beta_{12} x_{2}+\cdots+\beta_{1 p} x_{p}=\mathbf{x}^{t} \boldsymbol{\beta}_{1}$

and

$g_{2}(\mathbf{x})=\ln \left[\frac{\mathrm{p}(\mathrm{Y}=2 \mid \mathbf{x})}{p(\mathrm{r}=\mathrm{\alpha} \mid \mathbf{x})}\right]=\beta_{20}+\beta_{21} x_{1}+\beta_{22} x_{2}+\cdots+\beta_{2 p} x_{p}=\mathbf{x}^{t} \boldsymbol{\beta}_{2}$

Here the vector, $\mathrm{x}$, represents the length of $p+1$ where $x_{0}=1$. Following the above equations, the conditional probabilities of each outcome category are denoted as:

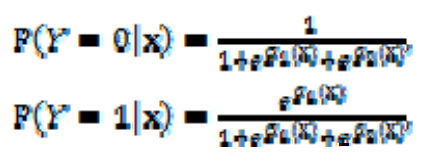

and

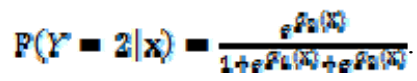

Letting $w_{f}(\mathbf{x})=\mathrm{P}(Y-k \mid \mathbf{x})$ for $\mathrm{j}=0,1,2$, the conditional likelihood function for a sample of $n$ observations is denoted as:

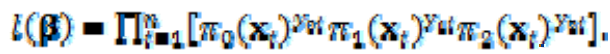

Here, taking the $\log$ and using the fact $\sum y_{j i}=1$ for each $i$, the $\log$ likelihood function can be defined as:

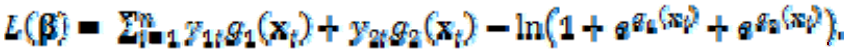

By taking the first partial derivatives of $E(\boldsymbol{\beta})$ with respect to each of the unknown parameters, the likelihood equations are denoted as:

$$
\frac{g L(B)}{g \beta_{t R}}=\sum_{i=1} x_{k i}\left(y_{g i}-\pi_{g h}\right)
$$

for $j=1,2$ and $k=0,1,2 \ldots, p$, with $x_{\mathrm{g}}=1$ for each subject.

The maximum likelihood estimator, $\widehat{\boldsymbol{\beta}}$, is obtained by letting the above-mentioned equations equal zero and solving for $\boldsymbol{\beta}$.

There are several ways to be admitted to a TEI in Indonesia, but almost all students gain admission through the national entrance examination. An individual cannot attend the university until passing the examination, regardless of his or her desire to so. Therefore, if the expected utility of entry into tertiary education is greater than that of work after secondary education, individuals cannot necessarily select the option that maximizes the utility, which is often the problematic case of the multi-nominal logit model (Nakamura 1993). Unfortunately, this study does not have suitable data to correct the problem. Instead, let us assume that a student completing secondary education knows his or her aptitude and is able to find a TEI that she can enter. Under this assumption, the individual compares the utility of entry into tertiary education and that of work, and decides which to pursue. The decision is also complicated by whether to pursue a diploma program or a bachelor's program. To address these considerations this study uses the multi-nominal logit model instead of the nested logit model.

\section{Data}

\section{Data Description}

The data used is from the fourth Indonesia Family Life Survey (IFLS4), which was conducted between 2007 and 2008 by the RAND Corporation, the Center for Population and Policy Studies (CPPS) of the University of Gadjah Mada, and Survey METRE. ILFS4 is an on-going longitudinal survey in Indonesia that began in 1993. The survey includes all of the data sets for the economic perspectives used in the conceptual framework of the study. As a 
whole, IFLS4 represents about 83 percent of the Indonesian population and contains 50,580 individuals living in 13 of 27 provinces $^{11}$ of the country. The survey provides information on personal characteristics of the population such as age, sex, education, and salary (the measurement unit is Indonesian Rupiah/ $\mathrm{IDR}^{12}$ ). Household information such as income, family size, and region of residence is also available. In addition, the survey includes education data such as the highest level of education attended, type of school, the name and location of school, test scores (EBTANAS/UAN/UN), school expenses, and scholarships received.

This study focuses on the traditional tertiary education population ages 19 to 25 who have completed secondary education. $^{13}$ Following the methodology of previous literature, students under and over the conventional age are not included in the sub-sample since they may generate distortions in the proposed analysis. Thus, 2,476 observations are extracted for the sub-sample. This study is also divided into urban and rural samples in order to estimate the difference between the two. The regional sub-samples number 1,547 for urban areas and 929 for rural areas. Distribution of sub-sampled persons is listed in Table 5.

Table 5. Distribution of Sub-sampled Persons Aged 19-25 by Region, IFLS4

\begin{tabular}{lrrrrrr}
\hline & Total & $(\%)$ & Urban & $(\%)$ & Rural & $(\%)$ \\
\hline Age 19-25 & 5,383 & 100 & 2,779 & 100 & 2,604 & 100 \\
$\begin{array}{l}\text { Enrolled in SSE (age } \\
\quad \text { 19-25) }\end{array}$ & 2,908 & 54 & 1,827 & 66 & 1,081 & 42 \\
$\begin{array}{l}\text { Not enrolled in SSE } \\
\quad \text { age 19-25) }\end{array}$ & 2,475 & 46 & 952 & 34 & 1,523 & 58 \\
Education Choice & & & & & & \\
$\quad$ Work/Others & 1,728 & 70 & 996 & 64 & 732 & 79 \\
$\quad$ Diploma & 288 & 12 & 204 & 13 & 84 & 9 \\
$\quad$ Bachelor's & 460 & 19 & 347 & 22 & 113 & 12 \\
$\quad$ Total & $\mathbf{2 , 4 7 6}$ & 100 & $\mathbf{1 , 5 4 7}$ & 100 & $\mathbf{9 2 9}$ & 100 \\
\hline
\end{tabular}

Note: SSE $=$ Senior Secondary Education.

Source: Created by Authors.

A few assumptions for sample selection should be discussed. First, samples of those who enter bachelor's, master or doctoral programs are combined because this study focuses on the difference of determinants between diploma and bachelor's programs. More importantly, the households which have tertiary age heads and spouses in IFLS4, and have had the same heads and spouses since IFLS3 conducted in 2000, are excluded in order to avoid other familial situations that might cause confusion. Consequently, the household heads and spouses are mostly the parents of the children, while the sub-sample also considers those households whose heads are not the parents of students, or whose heads are tertiary education age and have left their families to enroll in universities located in cities. ${ }^{14}$

\section{Model Specification and Explanation of Variables}

The dependent variable of this study is whether an individual is enrolled in a diploma program or a bachelor's program, or not enrolled in tertiary education whatsoever. Diploma programs and bachelor's programs are distinguished in this study because many people pursue diploma programs and there might be a difference between the determinants of access to diploma programs and bachelor's programs. The independent variables are classified as individual characteristics, scholastic characteristics, and regional characteristics other than family background.

Some suitable data are not available in IFLS. Let us take personal taste for example. It is complex, unstable and unique for each person. Therefore, following the example of previous studies, this study mainly focuses on objective determinants of student characteristics, and adopts other factors as long as data is available. Thus, the independent variables in this study are described below and listed in Table 6. The first independent variable is individual characteristic. Sex is adopted for the estimation, which takes a value of 1 if an individual is male, and a value of 0 in the case of female.

Familial characteristics are the second set of independent variable. Four variables are adopted for this variable set. First, the age of the household head is adopted based on previous literature (Nakamura 1993). It is assumed that the greater the age of the main householder, the greater the opportunities of entering tertiary education through greater assets. Second, educational level of the household head and spouse are used as proxy variables for parental education level. Both variables are regarded by previous studies as the most effective variables of children's educational behavior. Households with better-educated heads and spouses are likely to be more willing to provide incentives, information, and opportunities to send their children to TEIs. When the household head and spouse are parents, which is most often the case, the genetic and environmental transfer of human capital between parents and children influences the choice regarding tertiary education. Both variables are calculated in the form of years of schooling by the author in line with the DGHE definition. ${ }^{15}$ Third, sibling is defined as the number of household members. The variable is divided into the number of children age 0 to 14 and age 15 to 24 . The number of siblings in a family may have a negative effect on an individual's demand for tertiary education due to the decrease of family budget per household member. Fourth, family 
Table 6. Summary Statistics

\begin{tabular}{|c|c|c|c|}
\hline Variable & Description & Mean & Std. Dev. \\
\hline \multicolumn{4}{|c|}{ Dependent Variable } \\
\hline TERTIARY & $\begin{array}{l}\text { Tertiary enrolment status of a student } \\
(1=\text { diploma, } 2=\text { bachelor's, } 0=\text { work [others }])\end{array}$ & 0.49 & 0.79 \\
\hline \multicolumn{4}{|c|}{ Independent Variable } \\
\hline$S E X$ & $0-1$ dummy variable, $=1$ if individual is male & 0.48 & 0.50 \\
\hline$A G E H E A D$ & Age of household head & 52.44 & 9.34 \\
\hline EDUCHEAD & Highest education level in years of schooling of household head & 8.64 & 3.76 \\
\hline EDUCSPOUSE & Highest education level in years of schooling of spouse & 6.42 & 4.38 \\
\hline PC_HH_INC & $\begin{array}{l}\text { Family annual income per household member in millions of Indonesian } \\
\text { Rupiah }\end{array}$ & 7.48 & 6.27 \\
\hline AGE 0 TO 14 & Number of household members age $0-14$ & 1.02 & 1.11 \\
\hline$A G E 15$ TO 24 & Number of household members age 15-24 & 3.17 & 1.76 \\
\hline TESTSCORE & Senior secondary school UN score & 32.72 & 18.32 \\
\hline WORK $S$ & $0-1$ dummy variable, $=1$ if worked while attending high school & 0.10 & 0.29 \\
\hline$U R B A \bar{N}$ & $0-1$ dummy variable, $=1$ if individual lives in urban area & 0.62 & 0.48 \\
\hline GRDP_06 & GDP per capita by district in millions of Indonesian Rupiah & 14.84 & 13.20 \\
\hline$R \_E D \bar{U} C$ & Average years of schooling in the region of residence & 8.74 & 0.90 \\
\hline
\end{tabular}

Source: Created by Authors.

annual income ${ }^{16}$ per household member is adopted as one of the most important factors in this analysis. The unit of measurement is millions of Indonesian Rupiah. Students from rich families would have a greater propensity to go on to tertiary education since it is easier for them to finance the cost of education.

The third independent variable is scholastic characteristics. The total score on the national examination administered at the end of secondary education is adopted as the factor of academic aptitude. It is proposed that the differences by program may appear, and higher scholastic ability would be related to entry into more academic programs, namely bachelor's programs. Additionally, whether a student worked while in senior secondary school is taken into consideration. A value of one is assigned to an individual who worked while attending senior secondary education, and zero for those who did not work. Work during secondary is expected to have a positive effect on the decision to pursue diploma programs.Regional characteristics is the final independent variable. This study adopts three variables for regional characteristics. The first variable, whether or not a student lives in an urban or rural area, takes a value of zero for an individual living in a rural area, and takes a value of one for an individual living in an urban area. ${ }^{17}$ It is proposed that those who live in urban areas are more likely to go on to tertiary education since the opportunities to do so are greater mainly due to closer proximity to TEIs. Second, gross domestic product per capita by region is adopted for the estimation, and is measured in millions of Indonesian Rupiah. This study uses GRDP per capita estimated in 2006 since the sample data was collected in 2007 to 2008. This data is from Badan Pusat Statistik (BPS, 2009). The third variable, average years of schooling in the region of residence, is adopted and proposes that regional schooling level may provide incentives for entry into tertiary education, as well as create the opportunities for doing so through shared information or accommodation.

\section{Results}

Interpretation of the Results

The results of the multi-nominal logistic regression are reported in Table 7. The table shows the estimation for the specified total sub-sample age 19 to 25 divided into urban and rural. Each case reports independent variables with the regression coefficients, followed by the t-statistics in parentheses.

The education level of household head and per capita household income are the best predictors of an individual's choice to pursue tertiary education. The significant effects reported for each case are consistent with previous studies. However, family income is more significant compared to antecedents. In previous studies, family income is likely to be less significant compared to parental education level, especially in the case of access to nonselective tertiary education (Psacharopoulos and Soumelis 1979). Additionally, Chen (2009) shows the effect of household income on only boys' propensity to participate in tertiary education in Indonesia. This time, however, it is quite influential in all regressions although this study focuses on the difference by region. Meanwhile, the education level of spouse has a significant 
Table 7. Multi-nominal Logistic Regression of TE Choices, by Region

\begin{tabular}{|c|c|c|c|c|c|c|}
\hline & \multicolumn{2}{|c|}{ All } & \multicolumn{2}{|c|}{ Urban } & \multicolumn{2}{|c|}{ Rural } \\
\hline & Diploma & Bachelor's & Diploma & Bachelor's & Diploma & Bachelor's \\
\hline \multirow[t]{2}{*}{ SEX } & $-0.571 * * *$ & -0.253 & $-0.432 *$ & -0.229 & $-0.902 * *$ & -0.218 \\
\hline & $(-3.02)$ & $(-1.61)$ & $(-1.91)$ & $(-1.16)$ & $(-2.46)$ & $(-0.81)$ \\
\hline AGEHEAD & $(0.40)$ & $(1.62)$ & $(-0.35)$ & $(1.17)$ & $(1.32)$ & $(0.80)$ \\
\hline \multirow[t]{2}{*}{ EDUCHEAD } & $0.156^{* * *}$ & $0.199 * * *$ & $0.186^{* * *}$ & $0.259 * * *$ & $0.132 * * *$ & $0.138^{* * *}$ \\
\hline & $(5.21)$ & $(7.90)$ & $(4.83)$ & $(7.54)$ & $(2.61)$ & $(3.48)$ \\
\hline \multirow[t]{2}{*}{ PC_HH_INC } & $0.099 * * *$ & $0.118 * * *$ & $0.088 * * *$ & $0.114 * * *$ & $0.156^{* * *}$ & $0.122 * * *$ \\
\hline & $(5.50)$ & $(7.22)$ & $(4.30)$ & $(6.11)$ & $(3.83)$ & $(3.39)$ \\
\hline \multirow[t]{2}{*}{ AGE 0 TO 14} & 0.006 & -0.119 & -0.186 & $-0.334 * *$ & $0.457^{*}$ & 0.198 \\
\hline & $(0.05)$ & $(-1.11)$ & $(-1.28)$ & $(-2.47)$ & $(1.87)$ & (1.06) \\
\hline AGE 15 TO 24 & 0.065 & 0.072 & $0.144^{*}$ & 0.126 & -0.149 & -0.039 \\
\hline WORK_S & $(-1.28)$ & $(0.34)$ & $(0.15)$ & $(2.56)$ & $(-1.65)$ & $(-1.60)$ \\
\hline \multirow[t]{2}{*}{ URBAN } & -0.221 & -0.137 & & & & \\
\hline & $(-0.97)$ & $(-0.74)$ & & & & \\
\hline \multirow[t]{2}{*}{ GRDP_06_M } & -0.003 & $-0.021 * * *$ & -0.003 & $-0.021 * * *$ & -0.047 & $-0.113 *$ \\
\hline & $(-0.38)$ & $(-2.97)$ & $(-0.40)$ & $(-2.80)$ & $(-0.62)$ & $(-1.95)$ \\
\hline \multirow[t]{2}{*}{ R_EDUC } & 0.155 & -0.049 & $0.239^{*}$ & 0.008 & -0.060 & -0.250 \\
\hline & $(1.28)$ & $(-0.51)$ & $(1.71)$ & $(0.07)$ & $(-0.21)$ & $(-1.11)$ \\
\hline $\mathrm{N}$ & \multicolumn{2}{|c|}{1,428} & \multicolumn{2}{|c|}{916} & \multicolumn{2}{|c|}{512} \\
\hline $\mathrm{LH}$ & \multicolumn{2}{|c|}{-975.27} & \multicolumn{2}{|c|}{-629.21} & \multicolumn{2}{|c|}{-325.89} \\
\hline Pseudo R2 & \multicolumn{2}{|c|}{0.1558} & \multicolumn{2}{|c|}{0.1962} & \multicolumn{2}{|c|}{0.1102} \\
\hline
\end{tabular}

Source: Created by Authors.

Note: In each column, the estimates are listed first, followed by the t-statistic in parentheses

$\mathrm{N}=$ number of observations, $\mathrm{LH}=\log$ likelihood.

$* \mathrm{p}<=0.1 ; * * \mathrm{p}<=0.05 ; * * \mathrm{p}<=0.01$.

influence on access to tertiary education, and to a larger extent to bachelor's programs. However, it is not significant for rural areas.

National examination scores at the end of senior secondary education is a significant determinant of entry into tertiary education except in the case of rural areas. As test score is a wellknown predictor of access to tertiary, especially to more privileged education, it is consistent with the result in this analysis to some extent. However, it is more related to going to diploma programs than bachelor's programs. Moreover, it is not a significant determinant for rural residents.

Holding everything else constant, being male has a significant negative effect on belonging to a diploma program in total and in rural areas, and to a lesser extent in urban case. Female enrollment in Indonesia is rapidly increasing and has reached the same level as male enrollment. In addition, it is reported that more
Indonesian women have been entering the labor market recently (Ogawa and Masuma 2007). Given the current situation, it can be concluded that the recent expansion of female participation in the labor force has increased their need for more practical qualifications to bolster competitiveness in the labor market. However, the tendency is not relevant in the case of urban areas.

Age of household head has nothing to do with entry into tertiary education. Likewise, the average years of schooling in the district of residence is barely significant. It is of note, however, that living in urban areas does not impact an individuals' choices after completing secondary education in this analysis, even though there is serious access inequity between urban and rural areas. Analyses of other countries indicate the significance of these variables (Nakamura 1993; Mora 1997), but controlling for selected variables this is not true in the context of Indonesia. 
Instead of regional average of education level, regional income per capita has a significant negative effect on predicting the likelihood of participation in bachelor's programs in total and urban cases, and to a limited extent in rural case. This is because individuals would have more opportunities to participate in the labor market in more affluent areas. However, it does not have a correlation with access to diploma programs, perhaps indicating that diploma programs are more related to profession and not as affected by labor market conditions. This variable is somewhat controversial in previous studies in terms of its significance (Mora 1997; Handa and Skolnik 1975; Stafford et al. 1984). Other studies conclude that regional income affects demand for tertiary education. Higher income levels in wealthy regions could be an incentive for individuals to pursue tertiary education in order to find well-paid jobs. In the case of bachelor's programs in Indonesia, the former effect seems to be stronger than the latter. Note that it is not as significant in the case of rural areas.

The two variables regarding the number of siblings indicate somewhat complicated results. It is, however, clear that the number of children aged 0 to 14 in the household has a significant negative effect on the choice to pursue bachelor's programs for urban residents. This is partly consistent with the hypothesis of this study, but otherwise it does not show significance. Although it is incomprehensible that the number of siblings age 0 to 14 has a significant positive effect on access to diploma in rural areas and siblings age 15 to 25 has a significant positive effect on access to diploma in urban areas, the correlations are very little.

Contrary to the hypothesis, working status while attending high school has a significant positive effect on the likelihood of participation only in bachelor's programs in urban areas. There are many ways to interpret this result, but let us just say here that highly-motivated students work in order to continue their study, and consequently tend to pursue bachelor's programs in urban areas that provide many job opportunities. In opposition to the urban case, working status is negatively significant in belonging to diploma programs in the rural case, but has little statistical significance.

The important three variables of educational level of household head, family income per household member, and an individual's test score at the end of high school show relatively higher significances. In particular, education level of household head and per capita household income indicate statistically high correlation with education choices for all cases. These results are consistent with the existing literature conducted in developed countries.

In this analysis, the number of significant variables for urban residents is greater than that for rural residents. Also, goodness of fit measured by Pseudo R-squared is comparably lower in the rural sub-sample. This implies that there are other factors affecting the choice of pursuit for tertiary education in rural areas.

\section{The Case of Two Options}

In addition to the above analysis, this study estimates two options for future paths, entry into tertiary education or other options. Some Indonesian students take both of the exams for entry into a diploma and a bachelor's programs and go to the one they have passed. In this sense, there is a need to analyze the case in which students have two options after completing senior secondary schools, namely tertiary education or other options. This section aims to estimate the two options, and investigates to what extent each variable changes in terms of significance. The results of the logistic regression are reported in Table 8.

The results of Table 8 are quite similar to Table 7 . The exception is the variable for working status while attending high school changes its influences in the case of rural areas, and to a lesser extent in urban areas. Thus, it seems that there is not as large a change in terms of significance and this study maintains its validity to use the results from Table 7 for the estimation of access behavior by region.

\section{Discussion of Findings}

This study has focused on the issues of access and equity of Indonesian tertiary education. The study also investigated the determinants of access to diploma and bachelor's programs using data from IFLS4. To assess the gap by regions and family background, this study applied the existing literature, and examined the hypothesized regional access gap. The main findings of the study are reviewed below:

1. Family income has a significant positive effect on the choice of pursuing tertiary education in all cases, even when controlling for other variables.

2. It is notable that, if other variables are held constant, living in urban areas does not have a significant effect on the choice to pursue tertiary education, even though rural residents are dramatically underrepresented in tertiary education in Indonesia. Although there might be unobservable variables, the regional income per capita is more influential than living in urban areas. According to the results, it can be concluded that more variables are significant in more developed areas. On the other hand, in less developed areas, the influence of socioeconomic status is stronger. In addition, access to bachelor's 
programs for urban residents is the most likely to be affected by family background factors.

3. There is a difference in the determinants of access to tertiary education between urban and rural areas. Students living in urban areas are particularly affected by number of siblings, academic abilities, educational level of spouses, and working status while attending senior secondary schools. Meanwhile, being female, as well as socioeconomic factors, are more influential determinants in rural areas.

4. The education level of household parents and family income have significant influences on the choice to pursue tertiary education. This is obvious proof that a student's demand for tertiary education greatly depends on his or her parents. However, for rural residents, a spouse's education level is not significant.

5. This analysis also permits us to conclude that there are different determinants on the choices to pursue diploma and bachelor's programs. It is noteworthy that being male only has a significant negative effect on pursuing diploma programs. The recent expansion of female enrollment in tertiary education might result in a flow to diploma programs. On the other hand, the regional income per capita has a significant effect on access to a bachelor's program, if all other factors remain constant. However, the regional economic situation has no correlation with the decision to pursue a diploma program. This is consistent with Nizam's (2006) argument, that not many students demand quality tertiary education, but instead only need a diploma to enter the job market. To put it plainly, students do not seem to consider that completing a diploma program is significant to enjoy an advantage in the current job market. If this is true, the growing demand for diplomas would increase the employment mismatch more than before, and further efforts to eliminate it would be required.

Table 8. Logistic Regression of TE Choices, by Region

\begin{tabular}{|c|c|c|c|}
\hline & All & Urban & Rural \\
\hline \multirow[t]{2}{*}{ SEX } & $-0.374 * * *$ & $-0.309^{*}$ & $-0.445^{*}$ \\
\hline & $(-2.77)$ & $(-1.82)$ & $(-1.91)$ \\
\hline \multirow[t]{2}{*}{ AGEHEAD } & 0.011 & 0.007 & 0.017 \\
\hline & $(1.42)$ & $(0.67)$ & $(1.30)$ \\
\hline \multirow{2}{*}{ EDUCHEAD } & $0.183 * * *$ & $0.229 * * *$ & $0.136^{* *}$ \\
\hline & $(8.37)$ & $(7.80)$ & $(3.92)$ \\
\hline \multirow[t]{2}{*}{ EDUCSPOUSE } & $0.069 * * *$ & $0.070 * * *$ & 0.041 \\
\hline & $(3.87)$ & $(3.24)$ & $(1.24)$ \\
\hline \multirow[t]{2}{*}{ PC_HH_INC } & $0.111 * * *$ & $0.104 * * *$ & $0.134 * * *$ \\
\hline & $(7.34)$ & $(6.04)$ & $(4.20)$ \\
\hline \multirow[t]{2}{*}{ AGE 0 TO 14} & -0.067 & $-0.270 * *$ & $0.285^{*}$ \\
\hline & $(-0.75)$ & $(-2.37)$ & (1.78) \\
\hline \multirow[t]{2}{*}{ AGE 15 TO 24} & 0.071 & $0.134 *$ & -0.073 \\
\hline & $(1.31)$ & $(1.95)$ & $(-0.76)$ \\
\hline \multirow[t]{2}{*}{ TESTSCORE } & $0.010 * * *$ & $0.014 * * *$ & 0.007 \\
\hline & $(2.90)$ & $(3.07)$ & $(1.18)$ \\
\hline \multirow[t]{2}{*}{ WORK_S } & -0.109 & $0.620^{*}$ & $-0.783 * *$ \\
\hline & $(-0.46)$ & $(1.92)$ & $(-2.11)$ \\
\hline \multirow[t]{2}{*}{ URBAN } & -0.166 & & \\
\hline & $(-1.05)$ & & \\
\hline \multirow[t]{2}{*}{ GRDP_06 } & $-0.012 * *$ & $-0.012 * *$ & $-0.090^{*}$ \\
\hline & $(-2.23)$ & $(-2.08)$ & $(-1.81)$ \\
\hline \multirow[t]{2}{*}{ R_EDUC } & 0.026 & 0.098 & -0.180 \\
\hline & $(0.31)$ & (0.99) & $(-0.94)$ \\
\hline $\mathrm{N}$ & 1,428 & 916 & 512 \\
\hline LH & -705.35 & -442.03 & -247.43 \\
\hline Pseudo R2 & 0.1926 & 0.2416 & 0.1305 \\
\hline
\end{tabular}

Source: Created by Authors.

Note: In each column, the estimates are listed first, followed by the t-statistic in parentheses.

$\mathrm{N}=$ number of observations, $\mathrm{LH}=\log$ likelihood.

${ }^{*} \mathrm{p}<=0.1 ; * * \mathrm{p}<=0.05 ; * * \mathrm{p}<=0.01$. 
Being female, holding everything else constant, has a propensity for entry into diploma programs although the phenomenon is not the case with bachelor's programs. The Jakarta Post (24 January 2010) reports that the most significant change for women in Indonesia may be the rapid growth of women graduating from high schools. The increase of female graduates from high school expands female enrollment in tertiary education as shown in. In doing so, a diploma program would be more adaptable for them than a bachelor's program. Screening theory could be applicable here. Indonesian women need the higher level of qualification provided by diploma programs than men do in order to compete in the labor market. This is perhaps because there is discrimination towards women in the labor market, which is an extension of the foregoing discussion above. As females would be underrepresented in the labor market of Indonesia, the diploma program would help them compete in the labor market. However, further study is needed.

Overall, the important variables such as education level of household heads and spouses, family income, and test scores show significance. Students from urban areas are more likely to be affected these variables. As hypothesized earlier, rural residents are affected mainly by the socioeconomic status of their families. However, the result requires a more comprehensive study that subsumes other student and study characteristics.

On the other hand, this study reveals that regional factors are not as significant as expected. Living in urban areas and regional schooling averages are not correlated with the choice of entry into tertiary education. The regional disparity perceived is perhaps affected by another mechanism. In addition, this study put the number of TEIs by province as a variable of proximity into the model, but the significance was very little.

\section{Limitations of the Study}

Due to data limitations, some key variables were not included. Those are, for example, personal taste, employment perspectives, and supply side factors. Particularly, availability of employment and income expectations for tertiary education degree would permit us to investigate the applicability of human capital theory. It is possible to calculate the cost and earning from IFLS data by dividing working samples into tertiary and non-tertiary subsamples, and considering the lifetime earning expectation ( $\mathrm{Li}$ and Min 2001). However, this method would make the calculation more complicated and the result would be unstable. This should be a challenge for future studies. A nested-logit model could also be applied in order to consider the problem.

\section{Conclusion}

This study argues that family income remains a key factor of the choice to pursue tertiary education, but regional characteristics should carefully be considered. The access gap by income group already appears in the senior secondary level, and the sub-sample used in the analysis is from students completing at least senior secondary education. This means that the sub-sample supposedly represents those who can afford to pay for senior secondary education. Nevertheless, holding other variables such as education level of household head constant, the results from the econometric model reveal that family income is highly related to entry into further studies in Indonesia. Although some studies report a limited significance for familial economic status compared to parental education level, the results of this study indicate large significance for all cases. A tertiary degree will bring a higher salary for the future. The results imply that there is a cyclic structure based on family income that maintains the access gap between poor and rich families in both urban and rural areas. Thus, additional student aid such as scholarships, vouchers, student loans, and cross subsidies, or more cost-effective ICT use are still required in order to ensure access to tertiary education for all individuals who are "academically potential but financially disadvantaged" as manifested in HELTS IV (DGHE 2003, 3). These systems should be based on student characteristics rather than institutional characteristics (Salmi and Hauptman 2006). Also, parental education level and other characteristics should also be considered on this occasion, as this study has discussed.

Regarding regional characteristics, socioeconomic status and education level of household head are influential in urban areas, while only socioeconomic status is significant in rural areas. More importantly, living in urban areas is not correlated with the access to tertiary education in all cases. Also, the impact of provincial income per capita is different between urban and rural areas. Regional labor market conditions have little effect on access to tertiary education for rural residents, although the regional average of schooling is not significant in this study. Thus, this study reveals that there is not a consistent pattern for the regional characteristics on the demand for tertiary education in Indonesia. In terms of labor market conditions, size of the labor market, other regional characteristics involved, and specific job requirements should also be considered by further studies. Moreover, the determinants are different between the two tertiary programs, which implies that tertiary education policy is meeting, to some extent, the different demands of specific sub-groups.

This study also provides implications for tertiary education policy in Indonesia. More than one model demonstrates the impact of real choice behavior on tertiary education, and family 
background factors, such as the educational level of parents, are a complicated mechanism that affects the demand for tertiary education (Kodde and Ritzen 1988). Nevertheless, it would still be valuable to capture demand side behavior so that limited government resources may be better utilized to address the increasing diverse demand for tertiary education, and to enhance the nation's competitiveness through high-skilled human resources. This study hopes to build a base for continued discussion of development plans in developing countries like Indonesia. The expansion of tertiary education is a problem for both developed and developing countries. However, countries that are still developing are also required to adjust to global trends such as knowledge economy. In doing so, the demand for tertiary education will change. Currently, for example, the increasing tertiary education population is not adequately absorbed into the labor market. In other words, huge unemployment exists among graduates of tertiary education. The Jakarta Post (15 November 2009) reported that 13 percent, or 1.2 million, of Indonesia's unemployed held bachelor's degrees in 2009. The increasing demand for tertiary education will not reduce the mismatch between supply and demand in employment unless tertiary education plans, which are closely related to world of work, consider analyses on the demand for tertiary education. ${ }^{18}$ Such analyses should include the whole population and several types of tertiary education, including the demand for private TEIs, as this study examined.

\section{Notes}

1. According to the World Bank, tertiary education broadly refers to all post-secondary education. Universities are clearly a key part of all tertiary systems, but the diverse and growing set of public and private tertiary institutions in every country-colleges, technical training institutes, community colleges, nursing schools, research laboratories, centers of excellence, distance learning centers, and many more-form a network of institutions that support the production of the higher-order capacity necessary for development. In Indonesia, the definition of higher education is equivalent to tertiary education according to Director General on Higher Education (DGHE 2003).

2. Over the past 25 years, the number of school students increased two times for primary school, four and a half times for junior secondary school, eight times for senior secondary school, and ten times for tertiary education (Brodjonegoro 2004).

3. Additionally, there are Islamic TEIs, which are under MORA.
4. For example, some university teachers are employed in the form of public servant and their salary depends on the government budget (Nishino 2006).

5. The public TEIs have five ways to recruit new undergraduate students such as the national examination (Seleksi Penerimaan Mahasiswa Baru: SPMB), talent scouting by offering some schools to send their best students to the university (Triaswati and Roeslan 2003).

6. Martin Trow pointed out that higher education systems that enrolled up to 15 percent of the age group were elite systems; systems that enrolled between 15 percent and 50 percent of the age group were described as mass systems; and those that enrolled over 50 percent were universal systems (Trow 1974).

7. To make the age-earnings profiles, this study follows Psacharopoulos (1995). The predicted values calculated from the Mincerian earning function (Mincer 1974) are used for several missing values in cells of no-schooling and an outlier in a cell of junior secondary education. The estimated regression equation is:

Linkage

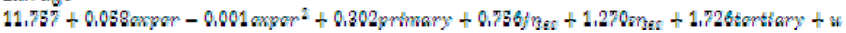

$\mathrm{N}=9,005, \mathrm{R}=0.285, \mathrm{~K}=0.28 \mathrm{~A}$

Hereinafter, "experience" is estimated as actual age minus estimated age at completion of schooling.

8. The term higher education instead of tertiary education is used interchangeably in this article used because most preceding studies use higher education although the differentiation of the terms varies by country.

9. Budria also says that this results in a source of intergenerational persistence of inequality, while it makes the differences in labor market performance with the same level of education as long as different higher education careers are associated with different wage and employment prospects.

10. This test means EBTANAS, or national examinations administered at the end of junior secondary schools, which is equivalent to UAN and UN. As of 2009, the term UN is generally used.

11. They are North Sumatra, West Sumatra, South Sumatra, Lampung, DKI Jakarta, West Java, Central Java, DI Yogyakarta, East Java, Bali, West Nusa Tenggara, South Kalimantan, and South Sulawesi. The other 14 of 27 provinces are excluded for mainly cost-effectiveness reasons but provinces are selected to balance the cultural and socioeconomic diversity, and to maximize the representation of the population. Note that the number of provinces has changed due to some political reasons, and there are 33 provinces in Indonesia as of 2009.

12. One IDR is equivalent to US\$0.00011 as of 31 January 2010.

13. Although tertiary education age population is often introduced as age group 18 to 24 (Johnstone and Marucci 2007, 6), some students at the age of 18 are still enrolled in secondary schools 
even if they are supposed to enroll in tertiary education. Hence, this study puts off the ages by a year.

14. In general, most previous studies chose tertiary education students who are living with their parents. However, this study includes such students since a lot of students live independently to go to TEIs in Indonesia. As a matter of fact, about 37 percent of tertiary education respondents completing senior secondary education are household heads or spouses in IFLS4 raw data. In order to do this, household identification numbers of IFLS3 (in 2000) are used when combining IFLS4 (in 2007) individual data with household data. This is why this study excludes those who have been household heads or spouses since 2000 IFLS.

15. This refers to DGHE (2003), and assumes that a diploma program lasts 2 years.

16. This study adopts annual expenditures to capture the household economic status. This is because expenditures are widely considered a standard measurement of economic status (Beegle, Frankenberg, and Thomas 1999).

17. The definition of urban and rural in IFLS follows that of 1993 National Socioeconomic Survey (SUSENAS), a socioeconomic survey designed by the Indonesian Central Bureau of Statistics (BPS).

18. Snodgrass (1991) predicted the employment mismatch since the civil service would diminish the share of a rapidly growing number of graduates from tertiary education in its employment and private sectors might not be able to keep pace with increase of the supply.

\section{References}

Albert, Cecilia. 2000. "Higher Education Demand in Spain: The Influence of Labour Market Signals and Family Background." Higher Education 40 (2): 147-162.

Altbach, Philip G. 2006. "Asian no daigaku niokeru kako to shorai: Niju-isseiki eno chosen (The Past and Future of Asian Universities: Twenty-first Century Challenges)." In Asia no kotokyoiku kaikaku, ed. by P. G. Altbach and T. Umakoshi, 12-37. Tokyo: Tamagawa University Press.

Arai, Kazuhiro. 1989. "A Cross-Sectional Analysis of the Determinants of Enrollment in Higher Education in Japan." Hitotsubashi Journal of Economics 30 (2): 101-120.

Asian Development Bank (ADB). 2005. "Higher Education Project in Indonesia." Project Performance Audit Report, Loan 1253-INO. Manilla: ADB. Available online at: http://www.adb.org.

Badan Pusat Statistik. 2009. Statistical Yearbook of Indonesia 2009. Jakarta: BPS-Statistics Indonesia.
Becker, Gary S. 1964. Human Capital: A Theoretical and Empirical Analysis, with Special Reference to Education. New York: Columbia University Press.

Becker, Gary S. 1981. A Treatise on the Family. Cambridge, MA: Harvard University Press.

Beegle, Kathleen, Elizabeth Frankenberg, and Duncan Thomas. 1999. Measuring change in Indonesia. Santa Monica, CA: RAND. Available online at: http://www.rand.org/.

Bishop, John. 1977. "The Effect of Public Policies on the Demand for Higher Education." The Journal of Human Resources 12 (3): 285-307.

Blau, Peter M., and Otis Dudley Duncan. 1967. The American Occupational Structure. New York: Wiley.

Borghans, Lex, Arnaud Dupuy, and Treena Wu. 2008. "Aggregate Shocks and How Parents Protect the Human Capital Accumulation Process: An Empirical Study of Indonesia." Paper presented at The Poverty, Equality and Growth Network Conference in conjunction with the Accra High Level Forum on Aid Effectiveness, Accra, Ghana, 2-4 September 2008. Available online at http://www.pegnet.ifw-kiel.de.

Brodjonegoro, Satryo Soemantri. 2004. "Indonesia.” In Handbook on Diplomas, Degrees and Other Certificates in Higher Education in Asia and the Pacific. 2nd ed., ed. UNESCO Bangkok. Bangkok: UNESCO.

Budria, Santiago. 2006. "Education and Inequality: Evidence from Spain." In Education and Wage in Europe: A Literature Review, ed. R. Asplund and E. Barth. Available online at: http://mpra.ub.uni-muenchen.de/.

Buhori, Mochtar, and Abdul Malik. 2006. "Indonesia ni okeru Kotokyoiku no Hatten (The Evolution of Higher Education in Indonesia)." In Asia no Kotokyoiku Kaikaku, ed. P. G. Altbach and T. Umakoshi. Tokyo: Tamagawa University Press.

Burnhill, Peter, Cathy Garner, and Andrew McPherson. 1990. "Parental Education, Social Class and Entry to Higher Education 1976-86." Journal of the Royal Statistical Society: Series A (Statistics in Society) 153 (2): 233-248.

Carpenter, Peter G., and Martin Hayden. 1993. "Improvement in the Equity in the Participation of Young People in Higher Education in Australia During 1980s." Higher Education 26 (2): 199-216.

Castells, Manuel. 1994. "The University System: Engine of Development in the New World Economy." In Improving Higher Education in Developing Countries. EDI Seminar Series, ed. A. Ransom, S. M. Khoo, and V. Selveratnam. Washington, DC: World Bank.

Chen, Dandan. 2009. "Vocational Schooling, Labor Market Outcomes, and College eEntry." Policy Research Working Paper 4814. Washington, DC: World Bank. 
Directorate General of Higher Education (DGHE). 2003. "Higher Education Long Term Strategy 2003-2010.” Jakarta: DGHE Ministry of National Education, Republic of Indonesia.

Fahmi, Mohamad. 2007. "Equity on Access of Low SES Group in the Massification of Higher Education in Indonesia." Working Paper in Economics and Development Studies, Department of Economics, Padjadjaran Univeristy. Available online at: http://www.equitablepolicy.org.

Flannery, Darragh, and Cathal O'donoghue. 2009. "The Determinants of Higher Education Participation in Ireland: A Micro Analysis." The Economic and Social Review 40 (1): 73-107.

Handa, Madan L., and Michael L. Skolnik. 1975. "Unemployment, Expected Returns, and the Demand for University Education in Ontario: Some Empirical Results." Higher Education 4 (1): 27-43.

Hansen, Devid O., Aziz Saleh, William L. Flinn, and Lawrence Hotchkiss. 1989. "Determinants of Access to Higher Education in Indonesia." Comparative Education Review 33 (3): 317-333.

Hayden, Martin, and Peter Carpenter. 1990. "From School to Higher Education in Australia." Higher Education 20 (2): 175-196.

Hopkins, Thomas D. 1974. "Higher Education Enrollment Demand." Economic Inquiry 12 (1): 53-65.

Hosmer, David W., and Stanley Lemeshow. 2000. Applied Logistic Regression. 2nd ed. New York: Wiley-Interscience.

International Comparative Higher Education Finance and Accessibility Project. 2006. Higher Education Finance and Cost-Sharing in Indonesia. Buffalo, NY: Graduate School of Education, University at Buffalo. Available online at: http://gse.buffalo.edu.

Jackson, Gregory A. 1978. "Financial Aid and Student Enrollment." The Journal of Higher Education 49 (6): 548-574.

Jiménez, Juan de Dios, and Manuel Salas-Velasco. 2000. "Modeling Educational Choices. A Binomial Logit Model Applied to the Demand for Higher Education." Higher Education 40 (3): 293-311.

Johnstone, D. Bruce, and Pamela N. Marcucci. 2007. "Worldwide Trends in Higher Education Finance: Cost-Sharing, Student Loans, and the Support of Academic Research." Prepared for The UNESCO Forum on Higher Education. Available online at: www.gse.buffalo.edu/org/IntHigherEdFinance.html.

Kodde, David A., and Jozef M. M. Ritzen. 1988. "Direct and Indirect Effects of Parental Education Level on the Demand for Higher Education." The Journal of Human Resources 23 (3): 356-371.

Kuo, Hsiang-Hui Daphne, and Robert M. Hauser. 1995. “Trends in Family Effects on the Education of Black and White Brothers." Sociology of Education 68 (2): 136-160.
Li, Wenli, and Weifang Min. 2001. "Tuition, Private Demand and Higher Education in China." PhD diss., Peking University.

Manski, Charles F., and David A. Wise. 1983. College Choice in America. Cambridge, MA: Harvard University Press.

Menon, Maria Eliophotou. 1998. "Factors Influencing the Demand for Higher Education: The Case of Cyprus." Higher Education 35 (3): 251-266.

Meyer, John W. 1970. "High School Effects on College Intentions." American Journal of Sociology 76 (1): 59-70.

Mincer, Jacob A. 1974. Schooling, Experience, and Earnings. New York: Columbia University Press.

Mingat, Alain, and J. C. Eicher. 1982. "Higher Education and Employment Markets in France." Higher Education 11 (2): 211-220.

Mora, José-Ginés. 1997. "Equity in Spanish Higher Education." Higher Education 33 (3): 233-249.

Nakamura, Jiro. 1993. "Kazoku zokusei to shingaku kodo ni kansuru jisshobunseki (An Empirical Analysis on Family Background and Advance to College)." Economic Journal 44 (3): 212-220.

Nelson, Joel I. 1972. "High School Context and College Plans: The Impact of Social Structure." American Sociological Review 37 (2): 143-148.

Nishino, Setsuo. 2006. "Indonesia." In Asia Oceania no koto kyoiku, ed. T. Umakoshi, Tokyo: Tamagawa University Press.

Nizam. 2006. "Indonesia." In Higher Education in South-East Asia, ed. UNESCO and South East Asian Ministers of Education Organization. Bangkok: UNESCO.

Ogawa, Keiichi and Akter Masuma. 2007. "Female Labor Force Participation in Indonesia." Journal of International Cooperation Studies 14 (3): 71-108.

Organisation for Economic Co-operation and Development (OECD). 1978. Individual demand for higher education: General Report. Paris: OECD.

Oshio, Takashi, and Wataru Senoh. 2003. "Nihon no kyoiku keizaigaku: Jisshobunseki no tenbo to kadai (Economics of Education in Japan: The Perspectives and Challenges in Empirical Analyses)." ESRI Discussion Paper Series No.69. Tokyo: Economic and Social Research Institute, Cabinet Office.

Petrongolo, Barbara, and María J. San Segundo. 2002. "Stayingon at School at 16: The Impact of Labor Market Conditions in Spain." Economics of Education Review 21 (4): 353-365.

Piachaud, David. 1975. "The Economics of Educational Opportunity." Higher Education 4 (2): 201-212.

Post, David. 1990. "The Social Demand for Education in Peru: Students' Choices and State Autonomy." Sociology of Education 63 (4): 258-271. 
Psacharopoulos, George. 1995. "The Profitability of Investment in Education: Concepts and Methods." Human Capital Development and Operational Policy Working Papers. Washington, DC: World Bank.

Psacharopoulos, George, and Harry Anthony Patrinos. 2002. "Returns to Investment in Education: A Further Update." Policy Research Working Paper No. 2881. Washington, DC: World Bank.

Psacharopoulos, George, and Costas Soumelis. 1979. "A Quantitative Analysis of the Demand for Higher Education.” Higher Education 8 (2): 159-177.

Psacharopoulos, George, Jee-Peng Tan, and Emmanuel Jimenez. 1986. Financing education in developing countries: An exploration of policy options. Washington, DC: World Bank.

Robbins Committee on Higher Education. 1963. Higher Education Report of Committee on Higher Education. London: Her Majesty's Stationery Office.

Salmi, Jamil, and Arthur Hauptman. 2006. "Innovations in Tertiary Education Financing: A Comparative Evaluation of Allocation Mechanisms." Working Paper Series, No. 4. Washington, DC: World Bank.

Schultz, Theodore W. 1961. "Investment in Human Capital." The American Economic Review 51 (1): 1-17.

Snodgrass, Donald R. 1991. "Indonesia.” In International Higher Education: An Encyclopedia. Vol. 1, ed. P. G. Altbach. New York: Garland.

Spence, Michael. 1973. "Job Market Signaling.” The Quarterly Journal of Economics 87 (3): 355-374.

Stafford, Kathy L., Sven B. Lundstedt, and Arthur D. Lynn, Jr. 1984. "Social and Economic Factors Affecting Participation in Higher Education." The Journal of Higher Education 55 (5): 590-608.

Tilak, Jandhyala B. G. 2003. "Higher Education and Development in Asia." Journal of Educational Planning and Administration 17 (2): 151-173.

Triaswati, Nina, and Femmy Roeslan. 2003. "Senior Secondary Education and Access to Higher Education. Higher Education Sector Study. " Japan Bank for International Corporation-DGHE.

Trow, Martin. 1973. Problems in the Transition from Elite to Mass Higher Education. Berkeley, CA: Carnegie Commission on Higher Education.

UNESCO. 2003. "Higher Education in Asia and the Pacific19982003." Technical Report, UNESCO, Asia and Pacific Regional Bureau for Education.

Williams, Trevor H. 1972. "Educational Aspirations: Longitudinal Evidence on Their Development in Canadian Youth." Sociology of Education 45 (2): 107-133.
Wills, Robert J., and Sherwin Rosen. 1979. "Education and SelfSelection." The Journal of Political Economy 87 (5): S7-S36.

World Bank, and UNESCO. 2000. Higher Education in Developing Countries: Peril and Promise. Washington, DC: World Bank.

Yuchtman, Ephraim, and Yitzhak Samuel. 1975. "Determinants of Career Plans: Institutional Versus Interpersonal Effects." American Sociological Review 40 (4): 521-531.

Ziderman, Adrian, and Douglas Albrecht. 1995. Financing Universities in Developing Countries. Washington, DC: Falmer Press.

Zhang, Jianxin. 2008. "ASEAN Higher Education on the Road from Elite to Massification.” Bangkok: UNESCO. 